\title{
Potential of Jackfruit Waste for Biogas, Briquettes and as a Carbondioxide Sink-A Review
}

\author{
Denis Nsubuga ${ }^{1}$, Noble Banadda ${ }^{1,2}$, Isa Kabenge ${ }^{1} \&$ Kerstin D. Wydra $^{3}$ \\ ${ }^{1}$ Department of Agricultural and Biosystems Engineering, Makerere University, Kampala, Uganda \\ ${ }^{2}$ Department of Agricultural and Biosystems Engineering, Ames, USA \\ ${ }^{3}$ Plant Production and Climate Change, Erfurt University of Applied Sciences, Erfurt, Germany \\ Correspondence: Denis Nsubuga, Department of Agricultural and Biosystems Engineering, Makekerere University, \\ P.O. Box 7062, Kampala, Uganda. Tel: 256-7-7964-8026. E-mail: dnsubuga5@gmail.com
}

Received: April 23, 2020

Accepted: June 12, $2020 \quad$ Online Published: July 29, 2020

doi:10.5539/jsd.v13n4p60

URL: https://doi.org/10.5539/jsd.v13n4p60

\begin{abstract}
One of the key aspects of a green economic development model of a country is to develop indigenous resources and local expertise while utilizing sustainable technologies. This review explored the possibilities of utilizing jackfruit waste for production of biogas, briquettes and biochar. In many of the developing countries, there is huge potential for organic waste conversion into appropriate energy solutions. These can contribute to developing rural areas especially small holder farmers and diversifying the available energy sources. Biomass waste like jackfruit waste when managed well can produce bio-energy, but also the GHG emissions need to be reduced from unmanaged, decomposing organic material. When put to use, agricultural biowastes like jackfruit waste could be used as raw materials in the production of bio-products (biofuels, biochar, bio pesticides), briquettes, among others. The biochar can be mixed with the soil producing carbon-rich soils and contribute to $\mathrm{CO}_{2}$ sequestration and soil fertility. This paper reviews works focused on using jackfruit waste for anaerobically producing of biogas, briquettes and biochar for improved crop production. The paper concluded that jackfruit waste can anaerobically decompose to produce biogas and it can also be used for briquette production. It was further concluded that jackfruit waste can undergo decomposition at high temperatures to produce biochar which can be incorporated into the soil creating a $\mathrm{CO}_{2}$ sink hence helping in mitigating the effects of the climate change.
\end{abstract}

Keywords: anaerobic digestion, biochar, biogas, briquettes, co-digestion, jackfruit and terra preta

\section{Introduction}

Sustainable energy contributes to sustainable development and to the seventh Sustainable Development Goal (SDG) which advocates for all people to access affordable and clean energy (United Nations Development Programme[UNDP], 2015). Additionally, all countries have to follow the resolutions of the UN Conference of Parties (COP 21) on climate change in Paris in the year 2015 to lower the greenhouse gases (GHG), in which renewable energy significantly contributes (United Nations Framework Convention on Climate Change [UNFCCC], 2015). Energy is very crucial in reducing poverty there by contributing towards attainment of the first SDG of reducing to zero the number people living below $\$ 1.90$ a day (World Bank, 2016) by 2030 through job opportunities for persons providing biogas, briquettes and biochar. Since the industrial revolution, energy has supported the growth of standards of living of the people in many countries from low to high income levels. Renewable energies are preferred for their ability to reduce the long lasting negative changes to natural environment and ecosystems due to emission of greenhouse gases (Moomaw et al., 2014). Crop residues and leftovers from agriculture are by-products of different agricultural activities in Uganda, but to-date few or no value addition takes place to these wastes. In many rural communities in Uganda, people mostly use firewood while others commonly use charcoal that severely contributed to degradation of woodland and forests.

Jackfruit is a tropical tree that bears fruits and originated from India (Ranasinghe \& Marapana, 2019). The fruit belongs to Genus Artocarpus and Moraceae (Mulberry) family (Sundarraj \& Ranganathan, 2018). Jackfruit is an evergreen tree about $8-25 \mathrm{~m}$ high and its fruits are considered to be the heaviest with an average weight about 80 $\mathrm{kg}$ (Nakintu, Olet, Andama, \& Lejju, 2019). Jackfruit has two varieties; the firm and soft varieties (Ranasinghe \& Maduwanthi, 2019; Priya, Suneta, Gupta, Thangam, \& Singh, 2014; Nakintu et al., 2019) with the perianth of the 
firm variety remaining hard at full ripening while that of the soft one turns soft and fleshy at ripening. The chemical and biological compositions have been reported to vary between the soft and firm jackfruits varieties (Ranasinghe \& Marapana, 2019). Jackfruit is an underutilized crop (Akter \& Haque, 2019), although its demand has increased due to its economical and nutritional benefits. Economically, jackfruit is gradually being valued in Uganda because of its potential to provide incomes for farmers with its marketing and consumption being evident in most towns in the country. Unlike other fruits, Jackfruit provides a number products ranging from food, timber, firewood, and medicinal herbs (Barua, Rahman, Parwary, Nahar, \& Ahmmed, 2016). It contains vitamin A and C, calcium, riboflavin, potassium, iron, sodium and zinc (Swami, Thakor, Haldankar, \& Kalse, 2012); Mondal et al., 2013). Another benefit of jackfruit nutritionally is its provision with phytonutrients like lignans, isoflavones and saponins which were suggested to contribute towards prevention of cancer. (Swami et al., 2012)

The edible portion of jackfruit is reported to be $25-35 \%$ while the waste contains $75-65 \%$ (Swami et al., 2012). Despite economic and nutritive value, jackfruit has attracted little research attention in Uganda probably because the largest part of the fruit is considered waste. However, a few studies have been done on its waste as animal feeds as reported by Ndyomugyenyi, Okot and Mutetikka (2014) and Nyamweha and kebirungi (2018). Other studies have revealed that jackfruit has an experimental Higher Heating Value (HHV) of $3.030 \mathrm{MJ} / \mathrm{Kg}$ (Pratiwi, Waluyo, Widyawidura, \& Noviansyah, 2019). Hence its waste can be densified into briquettes using an appropriate binder (Carnaje, Talagon, Peralta, \& Shah, 2018) to increase its calorific value (Vilela, Rezende, Carneiro, \& Silva 2016). These briquettes can be used to meet part of the energy requirements of households and industries (Emerhi, 2011).

Besides the briquettes, jackfruit waste is potential raw material for biochar through pyrolysis (Daful \& Chandraratne, 2018) given its carbon content (Ibrahim, Abid, Hanim, \& Zain, 2020). This biochar can be mixed with the soil to produce carbon-rich soils with properties similar to terra preta soils such as improved soil structures and microbial activity that improve the availability of nutrients required by plants (Winsley, 2007). This contributes to the attainment of the second SDG of ending hunger, ensuring that everyone is food secure with improved nutrition (UNDP, 2015). Given its sugar content, jackfruit waste has been digested anaerobically to produce biogas (Garrido, Conesa, \& Garcia, 2017). This biogas can supplement the energy requirements of households in the villages. It is therefore of utmost importance that possibilities of converting jackfruit waste into renewable energy are explored to increase its economic importance and reduce the negative environmental effects when this waste is poorly disposed-off. This paper reviews works on using jackfruit waste for anaerobically producing biogas and briquettes for energy provision as well as biochar for soil amendment.

\section{Production and use of Jackfruits in Uganda}

Jackfruit was introduced in Uganda in the 1890s by the Asians (Nakintu et al., 2019). Since then, many farmers in different districts have grown it although on small-scale. The major growing regions are the central, eastern and western regions of Uganda. Like in other jackfruit growing countries, two jackfruit varieties are produced in Uganda which are the soft and the firm varieties (Nakintu et al., 2019). These varieties have different local names in different languages and the firm variety jackfruits have bulbs with different colours (Table 1). Jackfruit bulbs are a delicacy among Ugandans with its marketing and consumption being evident in most towns of the country. Although the jackfruit bulbs are consumed by majority people in Uganda, its waste is normally given to animals as feed and in other cases, its discarded as waste. In Urban and peri-urban markets, the discarded waste is an environmental hazard because it attracts flies. However, some people in villages roast the jackfruit seeds and make a meal eaten with maize or potatoes (Ndyomugyenyi et al., 2014). Compared to its economical and nutritional benefits, jackfruit is still underutilized in Uganda and in many other countries where it is being grown.

Table 1. Jackfruit varieties in Uganda (Nakintu et al., 2019)

\begin{tabular}{lllll}
\hline Language & Soft variety & \multicolumn{3}{c}{ Firm variety } \\
& & Firm white & Firm Yellow & Firm red \\
\hline Luganda & Serebera, Njebu & Namata & Kanaanansi & Namusaayi \\
Lusoga & Erikutena & Edheru & Kapapali & Omutukuriki \\
Lugishu & Siwulo & Iwanga & Nabuloba & Imbesemu \\
Ateso & Enonok & Ekwang & Odosoikit & Ereng \\
Runyankole & Miluku & Erikweera & Eyakyenju & Erikutukura \\
Rukiga & Eyorobi & Eyamutale & Kinekye & Erikutukura \\
\hline
\end{tabular}




\subsection{Reasons for Underutilization of Jackfruit}

Although jackfruit has a number of health and nutritional benefits, it is underutilized and farmers rarely grow it in large scale because of its short shelf life with no processing facilities (Ranasinghe, Maduwanthi, \& Marapana, 2019). Jackfruit is very perishable and quickly loses flavour and browns on the surfaces (Mondal et al., 2013) which is undesirable. Following the harvesting, ripe jackfruits undergo rapid deterioration because of knowledge gaps on post-harvest practices and recommended storage facilities (Jagtap, Waghmare, Lokhande, Suprasanna, \& Bapat, 2011). In Uganda, many jackfruits are harvested prematurely and they ripen near markets which affects the taste. This is predominantly happening because of the increased demand of the fruit in urban areas as reported by (Nakintu et al., 2019).

Since jackfruits are highly perishable, they are usually exported as whole fruits and close to half of it consists of inedible waste materials making it less cost effective. Due to its inconsistence of the size and shape, designing jackfruit packaging materials is complicated while the thick skin and latex makes its preparation difficult. Also, the separation of jackfruit edible bulbs from jackfruit rind is a difficult and a quite labour intensive task making it unattractive to urban population with a busy lifestyle. The intense flavor of the flesh jackfruit makes it unacceptable to some consumers with a widespread belief that excessive consumption of it can lead to problems of digestion (Shrinath, Ramachandrayya, Haniadka, Dsouza, \& Bhat, 2011). The other issue is with the seeds whose moisture content is $55 \%$ making it hard to keep them if not properly dried (Mahanta \& Kalita, 2015). Despite the potential of jackfruit, few research works have been done to make use of its abundant waste (Ranasinghe \& Maduwanthi, 2019) creating research gaps that need to be filled.

\subsection{Major Parts of a Jackfruits}

Jackfruit has three main parts (Ranasinghe Maduwanthi, \& Maduwanthi, 2019): the fruit axis, the perianth and the bulbs. The axis contains the core, latex and the arils (Figure 1). Jackfruit has lactiferous cells which are responsible for production of latex (Ranasinghe \& Maduwanthi, 2019) which is sap that sticky in nature. The perianth contains the rind and the rags, the bulbs contain the edible part and the seeds (Figure 1). The inedible parts of jackfruit include prickly rind, non-edible perianth and a central core (Xu et al., 2018). All these inedible jackfruit parts are potential raw materials for bioenergy and biochar production.

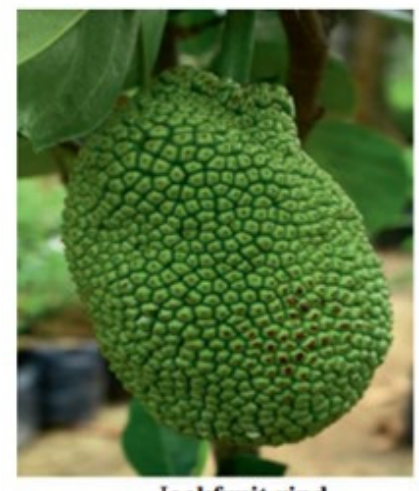

Jackfruit rind

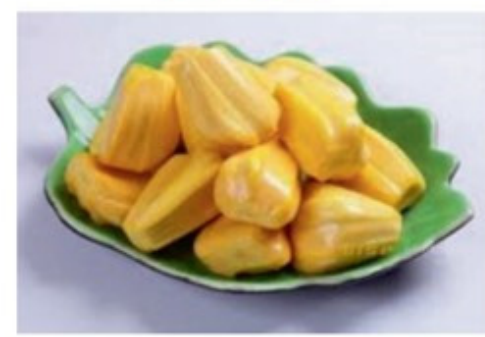

Bulbs

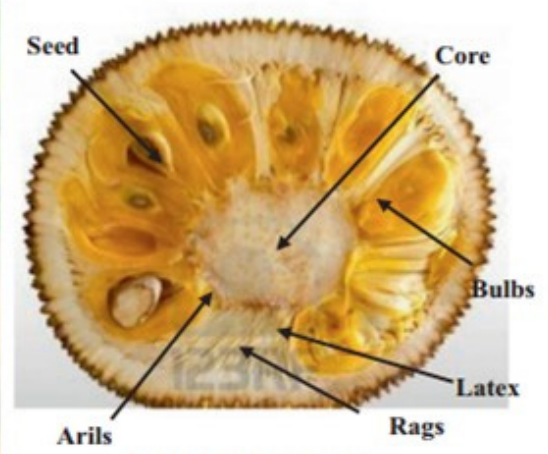

Cut section of Jackfruit

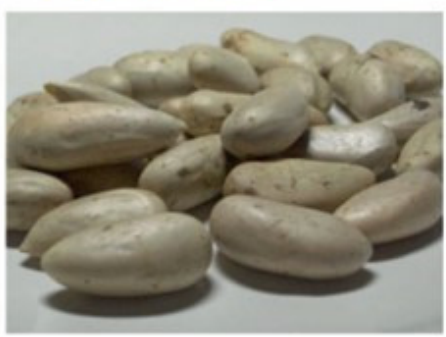

Seed

Figure 1. Parts of jackfruit (Swami, Ratnagiri, \& Kalse, 2018) 


\section{Potential of Jackfruit Waste for Biogas, Briquette and Biochar Production}

\subsection{Jackfruit Waste as Substrate for Anaerobically Producing Biogas}

Jackfruit contains sugars (Waghmare et al., 2019) and hence its waste can be anaerobically converted into biogas (Chakravarty, 2016). Likewise jackfruit seeds also contain non-reducing sugars which makes them suitable biogas substrates (Ranasinghe \& Maduwanthi, 2019). Jackfruit also contains digestible starch (Waghmare et al., 2019) which can hydrolyze into sugars (Ranasinghe \& Marapana, 2019). Specifically, jackfruit seeds are rich in digestible starch, protein and minerals (Akter \& Haque, 2019) which are required for producing biogas. Research has indicated that jackfruit fruit sugar content varies with the maturity stage with the minimum sugar content being in the immature stage and the maximum being in the over ripened jackfruit (Ranasinghe \& Marapana, 2019; Tiwari \& Vidyarthi, 2019). The sugar content increases during ripening, corresponding to a decline of the starch content because of hydrolysis of starch during ripening (Goswami et al., 2011). According to Li et al. (2017), it was also confirmed that during fruit ripening, there is increased starch hydrolysis and decreased respiration which results in increased sugar content. Therefore, for optimum sugar content, jackfruit should be used when fully ripened. However, the current trend of harvesting premature jackfruit and ripening them near markets in Uganda is likely going to affect biogas production from jackfruit waste although no detailed study has been done to quantity this effect. According to Goswami et al. (2011), other than the stage of ripening, variety also influences the total sugar content of jackfruit where two jackfruit varieties considered at full ripening showed values ranging from $11.29 \%$ to $17.89 \%$.

\subsubsection{Anaerobic Digestion of Jackfruit Waste for Biogas Production}

Anaerobic digestion is a process through which biogas is produced via microbiological breakdown of organic waste in absence of oxygen (Morales-polo, Cledera, \& Soria, 2018). This biological process takes place by different bacteria (Sebola, Tesfagiorgis, \& Muzenda, 2014). The by-product of this process, known as digestate is a potential agricultural fertilizer (Lošák et al., 2011; Walsh, Jiones, \& Williams, 2018; Clements, Salter, Banks, \& Poppy, 2012; Alburquerque et al., 2012) and hence can be used to improve crop production in nutrient deficient soils. Compared to the decomposing organic waste, the digestate does not smell and has less disease causing microorganisms with plant nutrients (Linville, Shen, Wu, \& Urgun-demirtas, 2015). Compared to aerobic treatment, the anaerobic process saves the energy for aeration, generates much less sludge (almost 50 time less) and also produces energy-rich biogas (Boileau and \& Merlin, 2015).

\subsubsection{Stages of Anaerobic Digestion}

Anaerobic digestion has four major stages (Menya, Alokore, \& Ebangu, 2013); hydrolysis, acidogenesis, acetogenesis and methanogenesis. The succession of this process depends on the interactions between the different microorganisms in the four stages (Meegoda, Li, Patel, \& Wang, 2018).

During the hydrolysis stage of producing biogas, undissolved compounds such as polysaccharides, proteins and fats are degraded into their monomers such as sugars, amino acids and fatty acids (Teghammar, 2013) which are potential biogas substrates. The second stage is the acidogenesis where acidogenic microorganisms absorb the products from hydrolysis and use it to produce intermediate volatile fatty acids (VFAs) and other products (Shabih et al., 2018) which include alcohols, hydrogen, ammonia and carbon dioxide (Teghammar, 2013).

The third stage is acetogenesis where volatile fatty acids longer than two carbon atoms, alcohols longer than one carbon atom and brunched chained and aromatic fatty acids are broken down further into acetic acid, hydrogen and carbon dioxide (Teghammar, 2013). The last stage is the methanogenesis. Under this stage, the end products of acetogenesis are used as raw materials to produce methane and carbon dioxide by the methanogenic microorganisms (Aboderheeba, 2013). Methanogenic microorganisms are the most sensitive to oxygen among the known bacteria and therefore, they are mostly anaerobic.

\subsubsection{Factors That Affect Biogas Production from Jackfruit Waste}

For optimum biogas production from jackfruit waste, some factors must be maintained within acceptable ranges. The first one is temperature with different microorganisms having different intervals, where their growth is optimal (Wang, Guo, \& Wen, 2019). Three temperature ranges are defined by (Teghammar, 2013) as psychrophilic $\left(10^{\circ} \mathrm{C}\right)$, methophilic $\left(37^{\circ} \mathrm{C}\right)$ and thermophilic $\left(50^{\circ} \mathrm{C}\right)$.

The substrates $\mathrm{pH}$ under digestion is an important factor and should be monitored for success and stability of the digestion process. A falling $\mathrm{pH}$ points towards acid accumulation (VFAs) and digester instability. Different microorganisms within the digester require different $\mathrm{pH}$ values but important to these are methanogens. These microorganisms quickly respond to $\mathrm{pH}$ change in the reaction. When the $\mathrm{pH}$ deviates from the optimum range for them, there will be a greater decrease in the methanogenic activity, which leads to a build-up of acetogenesis end 
products (Aboderheeba, 2013). Anaerobic processes are preferably run at a pH range of 7.0-8.5 (Teghammar, 2013), outside this range, the process faces imbalances.

The carbon-nitrogen ratio also affects biogas production from jackfruit waste. A high Carbon-Nitrogen ratio means methanogens are using more nitrogen than carbon and it results into less gas production (Rabii, Aldin, Dahman, \& Elbeshbishy, 2019). A low Carbon-Nitrogen ratio increases the concentration of ammonia and $\mathrm{pH}$ values up to 8.5, which is not favorable to methanogens (Pavithran, Kannan, Jayasingh, \& Karthikeyan, 2015). Optimum Carbon-Nitrogen ratios are between 20-30 to ensure maximum gas production (Aboderheeba, 2013). To maintain the Carbon-Nitrogen in the recommended range, low Carbon-Nitrogen substrates ratio like animal manure should be mixed with high Carbon-Nitrogen ratio substrates like organic waste.

Nutrient substrate content also affects biogas production since nutrients such as protein, fats and carbohydrates provide the energy required by the microorganisms (Teghammar, 2013) during anaerobic digestion. The nutrients needed for growth of microorganisms are carbon, nitrogen, hydrogen, phosphorus, potassium, Sulphur and iron.

\subsubsection{Some of the Earlier Studies of Biogas Production from Jackfruit Waste}

Even though jackfruit waste has sugars and starch required for biogas production, less research has been conducted to produce biogas from it compared to other fruits and vegetables like pineapples, mangoes and others. This has created a research gap that can be to be filled. Some of the studies conducted on jackfruit waste as a substrate in relation to biogas production and the possible research gaps are highlighted below.

Using mesophilic conditions, pineapples, oranges, jackfruit and bananas were co-digested with cow dung to produce biogas (Chakravarty, 2016). According to the results, co-substrates digestion produced the highest amount of biogas at 3 weeks followed by the cow dung which was a control substrate at a temperature of $36{ }^{\circ} \mathrm{C}$. This temperature disagreed with the temperature used in the earlier study by Pavithran et al. (2015) under the same mesophilic conditions. They maintained a temperature of $38{ }^{\circ} \mathrm{C}$ when studying the factors influencing biogas production using jackfruit as a substrate. Therefore, this is a knowledge gap that should be researched to ascertain the temperature at which optimum biogas production from jackfruit waste can be obtained.

According to Umeghalu, Okwonko, Ngini and Okoye (2015) and Pavithran et al. (2015), jackfruit waste was codigested jackfruit with chicken droppings and cow dung to enhance biogas production. However, both studies disagreed on the pretreatment method used. The study by Pavithran et al. (2015) pretreated jackfruit waste by reducing the substrate particle sizes and addition of tungsten as a catalyst and sodium hydrogen carbonate to control the $\mathrm{pH}$. The study by Umeghalu et al. (2015) also pretreated jackfruit waste by reducing the substrate particle sizes but after soaked it for 20 days before anaerobic digestion. Other researchers like (Amin et al., 2017) have proved that sodium hydroxide improves the digestibility of substrates and increase methane yield. However, no single study has evaluated these different pretreatment methods to find out which one works best with jackfruit waste. There is therefore a knowledge gap that should be researched to find out the best pretreatment method for jackfruit waste.

The studies conducted by Pavithran et al. (2015), Chakravarty (2016), Umeghalu et al. (2015), Victor, Shajin, Roshni, and Asha (2014) and Vijayaraghavan, Ahmad, and Ibrahim (2006) all concluded that jackfruit waste can anaerobically be digested to produce biogas. However, none of these studies further conducted experiments to find out if the jackfruit-based digestate could be used as potential organic fertilizer for growth of crops. This has created another gap in knowledge hence a need conduct field experiments with selected crops to ascertain if the jackfruitbased digestate can enhance crop growth as an organic fertilizer.

According to Kougias and Angelidaki (2018), improved monitoring of key parameters affecting biogas production will provide better utilization of different substrates. For example monitoring the $\mathrm{pH}$ helps to control unacceptable increase in VFAs since the more VFAs accumulate, the lower the pH gets (Rai, Tassew, Parajuli, \& Shah, 2016). Many of the jackfruit-based biogas experiments done in the laboratory are batch in nature. Such experimental setups don't permit periodical monitoring of key parameters like $\mathrm{pH}$ that highly affects the production of biogas. This creates a knowledge gap and hence more research works can be directed towards designing digester setups that that allow periodical monitoring of key parameters like $\mathrm{pH}$ for optimum biogas.

A study conducted by Victor et al. (2014) on augmentative invention of producing biogas from agronomic wastes using E. coli and Lactobacillus and jackfruit wastes, vegetable wastes and cow dung also produced biogas from jackfruit waste. The study observed that biogas production was more enhanced by the E. coli and Lactobacillus. The study also observed that lactobacillus is a better enhancer for more biogas production with short term period compared with the control condition although $E$. coli also acted as a modest range enhancer of producing biogas. Hence utilizing these two bacterial strains might tremendously enhance biogas production. 


\subsubsection{Enhancing Biogas Production from Jackfruit Waste by Pretreatment and Co-Digestion}

\section{Pretreatment of jackfruit waste}

As pointed out by Victor et al. (2014), Deepanraj, Velmurugan and Jayaraj (2013), Montgomery and Bochmann (2014), Tsapekos (2017), Karuppiah and Azariah (2018) and Westerholm, Castillo, Andersson, Nilsen, and Schnürer (2019), pretreatment of substrates enhances biogas production. Lignocellulosic materials derived from biological origin like jackfruit waste contain lignin, cellulose and hemicellulose (Raj \& Ranganathan, 2018) with greater percentage being cellulose (Sundarraj \& Ranganathan, 2017). This jackfruit composition requires pretreatment to optimize the volume of anaerobically produced biogas (Figure 2). An effective pretreatment method should be cost-effective and produce fewer inhibitors (Tayyab et al., 2018). Pretreatment is needed to alter structural and compositional hindrances to the hydrolysis process and subsequent degradation processes to enhance digestibility, improve enzyme hydrolysis and increase biogas yields (Aboderheeba, 2013). Substrate pretreatment methods include physical, chemical and biological methods (Kamusoko, Jingura, Parawira, \& Sanyika, 2019).

Physical pretreatment is employed first to break down the biomass size and crystallinity (Brodeur et al., 2011). It is done by shredding, grinding and milling (Tayyab et al., 2018). Milling as a pretreatment method does not produce compounds that are harmful to human beings hence a good choice for initial pretreatment of different lignocellulosic feedstock.

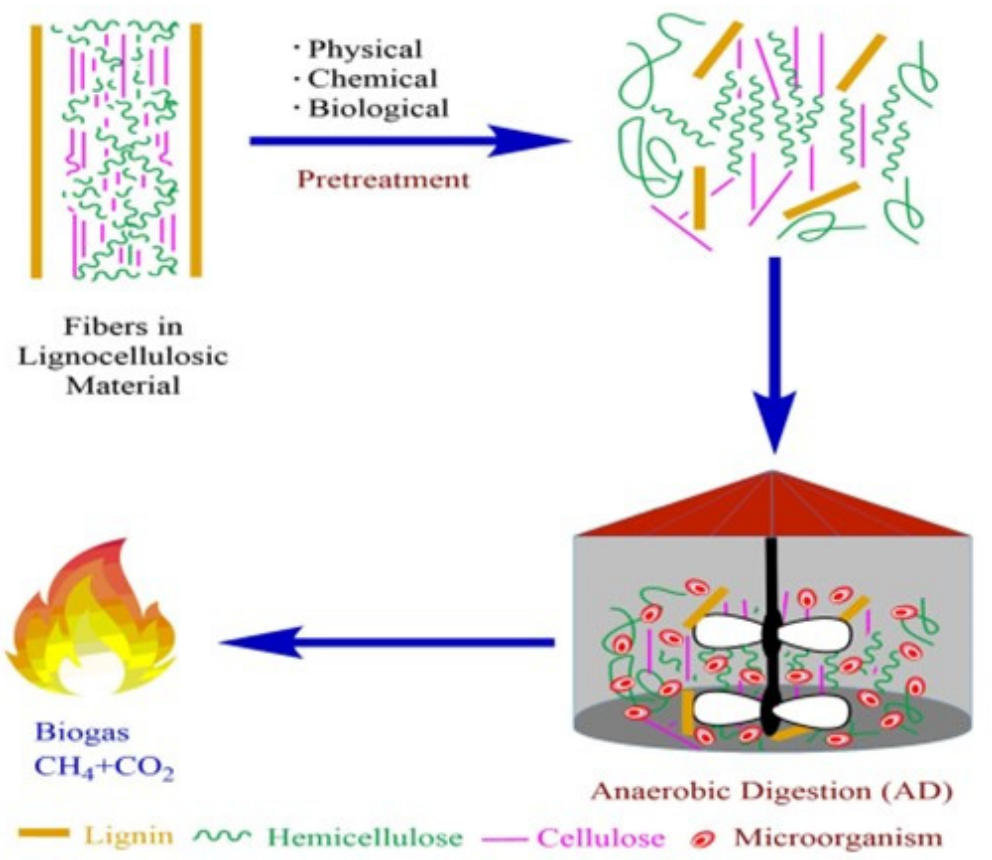

Figure 2. Schematic diagram showing pretreatment methods (Amin et al., 2017)

Chemical pretreatment was successfully used by Pavithran et al. (2015) to enhance biogas production from jackfruit waste. Acidic or alkaline solution are normally used for pretreatment of the biomass. However, although acid pretreatment can assist with the decomposition of substrates and to reduce the digestion time, its cost renders it financially ineffective compared to alkaline pretreatment (Meegoda et al., 2018). Alkaline pretreatment which mainly include ammonia and hydroxide compounds that don't cause corrosion of surfaces like acidic pretreatment and they work well at ambient temperatures (Meegoda et al., 2018). Alkaline pretreatment works on the principle that fibers will swell altering the structure of lignin and uncovering the substrate to microorganisms (Chen, Stevens, $\mathrm{Zhu}$, Holmes, \& $\mathrm{Xu}, 2013)$. As anaerobic digestion usually requires use of alkaline solutions to balance the $\mathrm{pH}$, alkaline pretreatments are preferred to acidic pretreatment.

The last pretreatment method is the biological method. The method employs natural microorganisms possessing enzymes (bacteria, brown-white and soft rot fungi) which are capable of cell wall decomposition (Tayyab et al., 2018). Additionally, high pressure, acids, alkali, high temperature or any reactive species are not compulsory for this pretreatment method (Zhang et al., 2011). The method has been successfully used by Victor et al. (2014).

Co-digestion of jackfruit waste. 
Studies conducted by Chakravarty (2016), Umeghalu et al. (2015), Rabii et al. (2019), Elniski, Chatterjee, Mondal and Doelle (2019) and (Nansubuga et al. (2015) concluded that co-digestion of substrates enhances biogas production compared to mono-digestion. Co-digestion is the combination of different substrates for improved biogas production (Attri, Sohpal, \& Dewan, 2016). However, it's important to note that when co-digesting substrates, the cost of transporting the co-substrates from the generation point to the biodigester should be put into consideration. Feedstocks with higher Carbon-Nitrogen ratios can be co-digested with lower Carbon-Nitrogen ratios substrates to achieve a nutrient balance and to avoid low biogas production due to unsuitable $\mathrm{C} / \mathrm{N}$ ratios (Hagos, Zong, Li, Liu, \& Lu, 2017; Alqaralleh, Kennedy, Delatolla, \& Sartaj, 2017).

\subsubsection{Jackfruit Waste Digestate as a Potential Fertilizer}

Other than biogas, anaerobic digestion produces semi-liquid by-product. This by-product is termed as the digestate. The digestate contains all the nutrients in the original feedstock and hence a potential organic fertilizer (Walsh et al., 2018; Notaris, Sørensen, Bjarne, Radziah, \& Eriksen, 2018). Jackfruit waste contains essential plant nutrients like nitrogen, phosphorus and potassium according to Waghmare et al. (2019). Hence its digestate could be potential fertilizer for crops production. This nutrient-rich fertilizer can either be applied manually through overflow outlet or through pretreatment for example drying before application (Phung, Roubik, Mazancova, Van, $\&$ Banout, 2018). Safe recycling of the digestate does not only require it to have the required plant nutrients, but also uncontaminated by undesirable materials (Teodorita et al., 2013). The digestate can as well be separated into solid and liquid parts. The solid part which is about $20 \%$ of the total digestate under goes compositing and applied to nutrient-deficient soils as a fertilizer (Kizito, Luo, Wu, Ajmal, \& Lv, 2017). The liquid fraction is about $80 \%$ of digestate produced after mechanical separation is nutrients-rich and hence can be applied as a liquid fertilizer to various crops (Chadwick et al., 2015). Despite its potential, no studies have been done to explore the possibilities of using jackfruit waste -based digestate as a fertilizer hence a research gap.

\subsection{Jackfruit Waste as a Briquette Production Raw Material}

A briquette often refers to block of highly flammable solid material used as fuel to start and maintain a fire (Zubairu \& Gana, 2014). Briquetting is a process of densification of biomass to produce homogeneous, uniformly sized solid pieces of high bulky density achieved using a binder (Kathuria, Maninder, \& Grover, 2012). Briquettes are mostly biomass and charcoal briquettes. These briquettes have proved to be effective in generating energy from agricultural waste (Onukak, Mohammed-dabo, Ameh, Okoduwa, \& Fasanya, 2017). Many briquette raw material sources have been used and newer ones are under investigations with a desire of using locally available materials for briquette production. Jackfruit waste is an organic waste from which briquettes have been produced (Waluyo, Pratiwi, \& Sukmawati, 2017; Pratiwi, Waluyo, Wigyawidura, \& Aridito, 2019) on addition to other agricultural wastes.

A study conducted by Pratiwi et al. (2019) with the aim of examining the potential of jackfruit waste to produce bio-energy in form of briquettes showed that particle size impacts on higher and lower heating values of charcoal briquettes. This observation was similar to what Sutrisno, Anggono, Suprianto, Kasrun and Siahaan (2017) observed. However, their findings disagree with the findings of Tembe, Azeh and Ekhumelo (2017) and Huko, Kamau and Ogola (2015) who found that the difference in the heating values of the three particle size briquettes was not significant. Therefore, this is a gap in knowledge that needs to be researched to find out how particle size affects the calorific values of jackfruit-based briquettes.

\subsubsection{Characterization of Jackfruit-Based Briquettes}

Briquettes are normally characterized by their moisture content, ash content, volatile matter, fixed carbon and the calorific values (Sukarta, Sastrawidana, Putu, \& Ayuni, 2018).

According to SNI standards, it is recommended that briquettes are kept at a moisture content below $8 \%$ (Waluyo $\&$ Pratiwi, 2018). Low moisture content makes the briquette combustion easier and storage life longer while higher moisture content can cause mould growth during storage (Ishii \& Furuichi, 2014). According to Josephat and David (2017), the calorific value reduces with an increase in moisture content while density, ignition and burning time increase with an increase in moisture content. The study by Mkini \& Bakari (2015) categorized the briquettes into high and low moisture content briquettes with average values of $29 \%$ (wet basis) and $12 \%$ (dry basis).

The ash content is that part of a solid that do not burn (Pathak, Mandavgane, \& Kulkarni, 2017) and the lower the ash content, the better the briquette in terms of combustion (Efomah \& Gbabo, 2015). Ash contains 50\% silica (Kraszkiewicz, Kachel-jakubowska, \& Niedziolka, 2017) which affects the heat production (Hasan et al., 2017) and the other composition contains clay, calcium and magnesium oxide. Ash affects how heat is transferred to the surface of a fuel (Akowuah, Kemausuor, \& Mitchual, 2012) and also increases dust emissions. 
Volatile matter content is the quantity of substance that evaporates due to decomposition of compounds still present in a solid other than water (Waluyo \& Pratiwi, 2018). High percentage of volatile matter indicates that the substance can easily ignite and burn although the combustion is fast and difficult to control (Pathak et al., 2017). However, when its value is low, it means the briquettes cannot easily ignite, but also once ignited, they will burn smoothly (Falemara, Joshua, Aina, \& Nuhu, 2018). The study by Waluyo and Pratiwi (2018) concluded that that the more the volatile matter, the more the smoke when the briquettes are turned on. Carbonization of the briquettes is advised in cases of high volatile matter content. During carbonization, organic matter is heated to temperatures of $425^{\circ} \mathrm{C}$ (Carnaje et al., 2018) in a low-oxygen environment (Quartey, 2014).

Fixed carbon is the carbon that remains after volatile matter, is released after burning (Sukarta et al., 2018). This value is different from the ultimate carbon since a given amount of carbon is released as hydrocarbons in volatile matter (Tamilvanan, 2015). Fixed carbon shows the fraction of char that remains after the devitalization phase and these carbons combine with oxygen to release heat. Fixed carbon present in the substance enhances the heat value since the amount of fixed carbon acts as a major generator of hear during combustion (Suryaningsih, Nurhilal, Yuliah, \& Mulyana, 2017).

The last briquette characterization parameter is the calorific value. According to Sofyan and Subiyanto (2014), Antwi-Boasiako and Acheampong (2016) and Arellano, Kato and Bacani (2015), calorific value is the main parameter for measurement of biomass fuel quality from different agricultural wastes. The study by Obi, Akubuo and Okwonkwo (2013) also concluded that the heating value is a very crucial combustion property because it shows the quantity of fuel required to generate a specific amount of energy. Determination of calorific values is experimentally done by the bomb calorimeter (Srivastava, Narnaware, Makwana, Singh, \& Vahora, 2014; Idah and Mopah 2013). The bomb calorimeter ensures precise combustion of biomass samples in the defined conditions (Kabenge et al., 2018).

Like any other agricultural waste, jackfruit waste can be put together with other agricultural residues for production of composite briquettes. According to Musa (2012), composite briquettes have enhanced carbon and hydrogen contents and heating values making them better alternatives to fossil fuels which anyway need to be abandoned due to their negative effect on the climate. Banana and jackfruit leaves with higher calorific values than jackfruit waste (Phichai, Pragrobpondee, Khumpart, \& Hirunpraditkoon, 2013) can be put together with jackfruit waste to produce composite briquettes with better characteristics. However, no single study has considered mixing jackfruit waste with banana and jackfruit leaves. Therefore, this is a gap in knowledge that requires to be filled by producing such briquettes and determining their characteristics. As far as jackfruit-based briquettes are concerned, their emissions in form of GHGs, toxic compounds and particulate matter also has to be considered. This still is another research gap, and most probably reduces the appropriateness of these briquettes for renewable energy production.

\subsubsection{Possible Binder for Jackfruit-Based Briquettes}

The binders are materials used for strengthening the briquettes and they are either combustible or non-combustible binders (Raju, Jyothi, Satya, \& Praveena, 2014). Tapioca starch is an example of combustible binders that used in the production of jackfruit-based briquettes (Zubair \& Gana, 2014; Tembe, Otache and Ekhuemelo, 2014) because its readily available. However, the study by Muazu and Stegemann (2015) noted that it is important to explore alternative binder sources to be used in biomass densification. Use of a binder can improve briquette properties like calorific values (Helwani, Fatra, Arifin, Othman, \& Syapsan, 2018).

Other forms of binders for jackfruit-based briquettes are cow dung, wheat flour and paper pulps (Shyamalee, Amarasinghe, \& Senanayaka, 2015). Other authors like Kaliyan and Morey (2010), Lumadue, Cannon and Brown (2012) and Hardianto, Pambudi and Irhamna (2018) have suggested use of natural binders like lignin at temperatures of $164{ }^{\circ} \mathrm{C}$. These binders are rarely used with many studies using starch as a binder, creating a knowledge gap that can be filled by researching on the possibilities of using it as a briquette binder for jackfruitbased briquettes.

\subsection{Jackfruit Waste for Biochar Production through Pyrolysis}

Other than biogas and briquette production, jackfruit waste is a potential raw material for production of biochar through pyrolysis (Smetanová, Dotterweich, Diehl, Ulrich, \& Fohrer, 2012) given its carbon captured by jackfruit plants during photosynthesis (Sohi, 2012). Pyrolysis is the decomposition of biomass thermal-chemically under limited supply of oxygen at elevated temperatures for production of different products such as biochar, charcoal and biodiesel depending operating conditions (Nsubuga, Banadda, \& Kiggundu, 2019). One of the great advantages of this process is that many types of raw materials can be used for example organic materials like jackfruit waste (Omulo et al., 2017) and inorganic materials like plastics (Owusu, Banadda, Zziwa, Seay, \& Kiggundu, 2017). Pyrolysis process can be broken into separate categories which predict yields based on 
temperature, heating rate and residual time (Cuthbertson, 2018). These categories include slow pyrolysis (350-550 ${ }^{0} \mathrm{C}$ ) according to (Kiggundu \& Sittamukyoto, 2019), fast pyrolysis $\left(600-1000{ }^{\circ} \mathrm{C}\right)$ and flash pyrolysis $(800-1100$ ${ }^{0} \mathrm{C}$ ) according to (Cuthbertson, 2018). Biochar production is favoured by lower heating rates and long residence times where components in the vapour phase continue to react with each other leading to formation of biochar (Jahirul, Rasul, Chowdhury, \& Ashwath, 2012). Given its low heating rate and long residence time, slow pyrolysis is therefore recommended for biochar production (Cuthbertson, 2018).

Conversion of biomass to biochar can greatly contribute towards achieving of soil amendments and long-term carbon sequestration (Kiggundu \& Sittamukyoto, 2019). Soil carbon sequestration is a major means of reducing $\mathrm{CO}_{2}$ in the atmosphere and it is getting more interest of both scientific and civil sector because of its potential mitigating role against negative climate change effects (Doughty et al., 2013). Soil sequestration implies transferring atmospheric $\mathrm{CO}_{2}$ in pools and storing it in soil as a $\mathrm{CO}_{2}$ sink for long term to mitigate the negative climate change effects (Kumar, Kumar, Kakraliya and Jangir, 2017). Soil carbon sequestration can be achieved through biochar addition to the soil among other methods. Over the years, soil studies have attracted researchers as a sink for the atmospheric $\mathrm{CO}_{2}$ (Singh et al., 2018). Biochar can be incorporated into the soil using either power tiller or ox-plough without affecting its performance (Ndhlovu, Kiggundu, Wanyama, \& Banadda, 2017).

The use biochar application for soil amendment and carbon sequestration is not new. It has been found in areas of the fertile terra preta soils of the central Amazon basin in South America, the plaggen soils of North-West Europe and the ancient agricultural soils of the Andes (Downie, Zwieten, Smernik, Morris \& Munroe, 2011). The terra preta soils in the Amazon have higher levels of soil organic matter, improved nutrients holding capacity, higher $\mathrm{pH}$ and higher moisture holding capacity compared to the surrounding soils. These soils have a clear anthropogenic origin involving the addition of charred organics (biochar), the remnants from earthed ovens used for cooking and firing pottery by the inhabitants to the surrounding soils (Downie et al., 2011). Thus, carbon stocks have remained high in these soils up to today, many years after abandonment. This has provided a basis for benefits of adding biochar to soils both in terms of carbon sequestration and soil amendment (Stoyle, 2011).

However, it should be noted that the way biochar effects soils and crop productivity cannot be generalized since it depends on raw material used, crops being tested and site where biochar is applied (Lorenz \& Rattan, 2014). At the moment, no study has been reported on the potential of jackfruit waste as raw material for biochar production to improve soil properties and mitigating the negative climate change impacts hence a research gap. The studies done so far have utilized jackfruit waste-based biochar for briquette production (Waluyo et al., 2017; Pratiwi et al., 2019) and adsorption of heavy metals from water (Abid, Ibrahim, \& Zulkifli, 2019; Ibrahim et al., 2020). Results from such a study will support the outcomes of United Nations COP 21 conference which advocated for the increase of organic soil carbon stocks to improve food security and mitigate the negative climate change impacts (Demenois, 2018).

\section{Conclusion}

The review concluded that given its starch, sugar and nutrient content, jackfruit waste can be anaerobically digested to produce biogas with higher gas volumes achieved through pretreatment and co-digestion of the substrate. However, little attention has been given to the potential of the jackfruit waste-based digestate for further utilization yet anaerobic digestion can produce large volumes of this digestate hence need for a detailed study to suggest ways of utilizing it. It was further concluded that jackfruit waste can also be used for production of briquettes given its higher heating values although different researchers have disagreed on the particle size effect on the briquette higher and lower heating values hence a research gap that need to be filled. The review also concluded that jackfruit waste is a potential raw material for biochar production through pyrolysis given its carbon content and that this biochar can be used for production of briquettes, adsoption of heavy metals in water and for soil amendment

\section{Acknowledgments}

The authors would like to thank the Fruits and Vegetables for All Seasons (FruVaSe) project for funding this work through Makerere University.

\section{References}

Abid, M. K., Ibrahim, H. B., \& Zulkifli, S. Z. (2019). Synthesis and characterization of biochar from peel and seed of jackfruit plant waste for the adsorption of copper metal ion from water. Research Journal of Pharmacy and Technology, 12(9), 4182-4188. https://doi.org/10.5958/0974-360X.2019.00720.0

Aboderheeba, A. K. M. (2013). Novel approach to pretreatment of agricultural products and food waste to improve biogas production (Unpublished Ph.D thesis). Dublin City University, Dublin, Ireland.

Akowuah, J. O., Kemausuor, F., \& Mitchual, S. J. (2012). Physico-chemical characteristics and market potential 
of sawdust charcoal briquette. International Journal of Energy and Environmental Engineering, 3(1), 1-6. https://doi.org/10.1186/2251-6832-3-20

Akter, F., \& Haque, M. A. (2019). Jackfruit Waste : a Promising Source of Food and Feed. Ann. Bangladesh Agric., 23(1), 91-102.

Alburquerque, A., D, C., Ferrer-costa, A., Fuente C., Cegarra, J., Carrasco L., Bernal P., M., \& Abad, M. (2012). Assessment of the fertiliser potential of digestates from farm and agroindustrial residues, 40, 181-189. https://doi.org/10.1016/j.biombioe.2012.02.018

Alqaralleh, R., Kennedy, K., Delatolla, R., \& Sartaj, M. (2017). Biogas Recovery from Hyper-Thermophilic Anaerobic Co-Digestion of Thickened Waste Activated Sludge , Organic Fraction of Municipal Solid Waste and Fat , Oil and Grease. Journal of Biomediation and Biodegradation, 8(5), 1-5. https://doi.org/10.4172/2155-6199.1000408

Amin, F. R., Khalid, H., Zhang, H., Rahman, S., Zhang, R., Liu, G., \& Chen, C. (2017). Pretreatment methods of lignocellulosic biomass for anaerobic digestion. AMB Express, 7(72). https://doi.org/10.1186/s13568-0170375-4

Antwi-Boasiako, C., \& Acheampong. (2016). Strength properties and calorific values of sawdust-briquettes as wood-residue energy generation source from tropical hardwoods of different densities. Biomass and Bioenergy, 85, 144-152. https://doi.org/10.1016/j.biombioe.2015.12.006

Arellano, G. M. T., Kato, Y. S., \& Bacani, F. T. (2015). Evaluation of Fuel Properties of Charcoal Briquettes Derived From Combinations of Coconut Shell, Corn Cob and Sugarcane Bagasse. In Proceeding of the DLSU Research Congress, 3, 1-6.

Attri, I., Sohpal, V. K., \& Dewan, N. (2016). A Review- Pretreatment Methods and Anaerobic Co- Digestion of Biomasses for Biogas Production. The Research Journal (TRJ): A Unit of 12OR, 2(2), 41-45.

Barua, H., Rahman M., Partwary A. M. M., Nahar S., \& Ahmmed F. N. A. (2016). Evaluation of Yield and Quality of Three Jackfruit (Artocarpus heterophyllus L.). The Agriculturalist, 14(1), 107-111. https://doi.org/10.3329/agric.v14i1.29108

Boileau, \& Merlin. (2015). Anaerobic Digestion of Agricultural Waste: State of the Art and Future Trends. Retrieved March 4, 2020, from https:/www.researchgate.net/publication/257214833_Anaerobic_Digestion_of_Agricultural_Waste_State_o f the_Art_and_Future_Trends

Brodeur, G., Yau, E., Badal, K., Collier, J., Ramachandran, K. B., \& Ramakrishnan, S. (2011). Chemical and physicochemical pretreatment of lignocellulosic biomass: A review. Enzyme Research, (1), 1-17. https://doi.org/10.4061/2011/787532

Carnaje, P. N., Talagon, B. R., Peralta, P. J., Shah, K., \& Ferreiro, P. J. (2018). Development and characterisation of charcoal briquettes from water hyacinth (Eichhornia crassipes) -molasses blend. PLOSE ONE, 13(11), 114. https://doi.org/https://doi.org/10.1371/journal.pone.0207135

Chadwick, D., Wei, J., Yan, T., Guanghui, Y., Qirong, S., \& Qing, C. (2015). Agriculture , Ecosystems and Environment Improving manure nutrient management towards sustainable agricultural intensi fi cation in China. Agriculture, Ecosystems and Environment, 209, 34-46. https://doi.org/10.1016/j.agee.2015.03.025

Chakravarty, G. (2016). Evaluation of fruit wastes as substrates for the production of biogas, 7(3), 25-28.

Chen, Y., Stevens, M. A., Zhu, Y., Holmes, J., \& Xu, H. (2013). Understanding of alkaline pretreatment parameters for corn stover enzymatic saccharification. Biotechnology for Biofuels, 6(8), 2-11.

Clements, L. J., Salter, A. M., Banks, C. J., \& Poppy, G. M. (2012). The usability of digestate in organic farming. Water Science Technoolgy, 66(9), 1864-1870. https://doi.org/10.2166/wst.2012.389

Cuthbertson. (2018). The Production of Pyrolytic Biochar for Addition in Value-Added Composite Material (Unpublished Master's thesis). The University of Western Ontario, Ontario, Canada.

Daful, A. G., \& Chandraratne, M. (2018). Biochar Production From Biomass Waste-Derived Material. Encyclopedia of Renewable and Sustainable Materials, (January), 370-378. https://doi.org/10.1016/b978-012-803581-8.11249-4

Deepanraj, B., Sivasubramanian, V., \& Jayaraj, S. (2013). Enhancement of biogas production by pretreatment: A review. Proceesings of the IVth International conference on Advances in Energy Research, Indian Institute of 
Technology. Bombay, Mumbai, India. https://doi.org/10.1016/j.jbusres.2011.09.016

Demenois, J. (2018). The 4 per 1000 Initiative: soils for food security and climate. Proceedings of the Global Science Conference from 16-18 , March, 2015. Le Corum, Montpellier France. https://doi.org/10.13140/RG.2.2.28859.67362

Doughty, C. E., Metcalfe, D. B., da Costa, M. C., de Oliveira, A. A. R., Neto, G. F. C., Silva, J. A., \& Malhi, Y. (2013). The production, allocation and cycling of carbon in a forest on fertile terra preta soil in eastern Amazonia compared with a forest on adjacent infertile soil. Plant Ecology and Diversity, 7(1-2), 41-53. https://doi.org/10.1080/17550874.2013.798367

Efomah, A. N., \& Gbabo, A. (2015). The Physical, Proximate and Ultimate Analysis of Rice Husk Briquettes Produced from a Vibratory Block Mould Briquetting Machine. International Journal of Innovative Science, Engineering and Technology, 2(5), 814-822.

Elniski, A. R., Chatterjee, S. G., Mondal, C., \& Doelle, K. (2019). Effects of Substrate to Inoculum Ration on Biogas Production from Anaerobic Co-digestion of Office Paper and Cow Manure. Journal of Energy and Research Reviews, 3(4), 1-15. https://doi.org/10.9734/JENRR/2019/v3i430112

Emerhi, E. A. (2011). Physical and combustion properties of briquettes produced from sawdust of three hardwood species and different organic binders. Advances in Applied Science Research, 2(6), 236-246.

Falemara, B. C., Joshua, V. I., Aina, O. O., \& Nuhu, R. D. (2018). Performance Evaluation of the Physical and Combustion Properties of Briquettes Produced from Agro-Wastes and Wood Residues. Recycling, 3(37), 113. https://doi.org/10.3390/recycling3030037

Garrido, M. A., Conesa, J. A., \& Garcia, M. D. (2017). Characterization and Production of Fuel Briquettes Made from Biomass and Plastic Wastes. Energies, 10(850). https://doi.org/10.3390/en10070850

Goswami, C., Hossain, M. A., Kader, H. A., \& Islam, R. (2011). Assessment of Physicochemical Properties of Jackfruits' (Artocarpus heterophyllus Lam) Pulps. Journal of Horticulture, Forestry and Biotechnology, 15(3), $26-31$.

Hagos, K., Zong, J., Li, D., Liu, C., \& Lu, X. (2016). Anaerobic co-digestion process for biogas production: Progress, challenges and perspectives. Renewable and Sustainable Energy Reviews, 76, 1485-1496. https://doi.org/10.1016/j.rser.2016.11.184

Hardianto, T., Pambudi, F. F., \& Irhamna, A. R. (2018). A study on lignin characteristic as internal binder in hot briquetting process of organic municipal solid waste. AIP Conference Proceedings 1984 030013-030013-10. https://doi.org/10.1063/1.5046634

Hasan, E. S., Jahiding, M., Mashuni, Ilmawati, W. O. S., Wati, W., \& Sudiana, I. N. (2017). Proximate and the Calorific Value Analysis of Brown Coal for High-Calorie Hybrid Briquette Application. Journal of Physics: Conference Series, 846, 012022. https://doi.org/10.1088/1742-6596/846/1/012022

Helwani, Z., Fatra, W., \& Syapsan. (2018). Effect of process variables on the calorific value and compressive strength of the briquettes made from high moisture Empty Fruit Bunches (EFB). Proceedings of IOP Conf. Series: Material Scince and Engineering from 29-30 ${ }^{\text {th }}$ November, 2017 in Pekambaru-Riau, Indonesia. https://doi.org/10.1088/1757-899X/345/1/012020

Huko, D., Kamau, D. N., \& Ogola, W. O. (2015). Effects Of Varying Particle Size On Mechanical And Combustion Characteristics Of Mango Seed Shell Cashew Nut Shell Composite Briquettes. International Journal of Engineering Science Invention, 4(5), 32-39.

Ibrahim, H., Abid, M. K., Hanim, H., \& Zain, M. (2020). Heavy Metal Ions Adsorption from Aqueous Solution by Jackfruit Peel as Activated Biochar Low-Cost Adsorbent. Journal of Advanced Research in Fluid Mechanics and Therma Sciences, 2(2), 154-165.

Idah, P. A. \& Mopah, E. J. (2013). Comparative Assessment of Energy Values of Briquettes from Some Agricultural By-Products with Different Binders. Journal of Engineering, 3(1), 36-42.

Ishii, K., \& Furuichi, T. (2014). Influence of moisture content , particle size and forming temperature on productivity and quality of rice straw pellets. Waste Management, 34, 2621-2626. https://doi.org/10.1016/j.wasman.2014.08.008

Jagtap, U. B., Waghmare, S. R., Lokhande, V. H., Suprasanna, P., \& Bapat, V. A. (2011). Preparation and evaluation of antioxidant capacity of Jackfruit (Artocarpus heterophyllus Lam.) wine and its protective role against radiation induced DNA damage. Industrial Crops \& Products, 34(3), 1595-1601. 
https://doi.org/10.1016/j.indcrop.2011.05.025

Jahirul, M. I., Rasul, M. G., Chowdhury, A. A., \& Ashwath, N. (2012). Biofuels production through biomass pyrolysis- A technological review. Energies, 5(12), 4952-5001. https://doi.org/10.3390/en5124952

Josephat, W., \& David, K. C. (2017). Effect of the Briquette Sizes and Moisture Contents on Combustion Characteristics of Composite Briquettes. International Journal of Innovative Science, Engineering and Technology, 4(7), 102-111.

Kabenge, I., Omulo, G., Banadda, N., Seay, J., Zziwa, A., \& Kiggundu, N. (2018). Characterization of Banana Peels Wastes as Potential Slow Pyrolysis Feedstock. Journal of Sustainable Development, 11(2), 14. https://doi.org/10.5539/jsd.v11n2p14

Kaliyan, N., \& Morey, R. V. (2010). Natural binders and solid bridge type binding mechanisms in briquettes and pellets made from corn stover and switchgrass. Bioresource Technology, 101(3), 1082-1090. https://doi.org/10.1016/j.biortech.2009.08.064

Kamusoko, R., Jingura, R. M., Parawira, W., \& Sanyika, W. T. (2019). Comparison of pretreatment methods that enhance biomethane production from crop residues - a systematic review, 24, 1080-1089. https://doi.org/10.18331/BRJ2019.6.4.4

Karuppiah, T., \& Azariah, V. E. (2018). Biomass Pretreatment for Enhancement of Biogas Production. Intech Open. https://doi.org/http://dx.doi.org/10.5772/intechopen.82088

Kathuria, R. S., \& Grover, S. (2012). Using Agricultural Residues as a Biomass Briquetting : An Alternative Source of Energy. Journal of Electrical and Electronics Engineering, 1(5), 11-15.

Kiggundu, N., \& Sittamukyoto, J. (2019). Pryloysis of Coffee Husks for Biochar Production. Journal of Environmental Protection, 10(12), 1553-1564. https://doi.org/10.4236/jep.2019.1012092

Kizito, S., Luo, H., Wu, S., Ajmal, Z., \& Lv, T. (2017). Phosphate recovery from liquid fraction of anaerobic digestate using four slow pyrolyzed biochars : Dynamics of adsorption , desorption and regeneration. Journal of Environmental Management, 201, 260-267. https://doi.org/10.1016/j.jenvman.2017.06.057

Kougias, P. G., \& Angelidaki, I. (2018). Biogas and its opportunities - A review. Frontiers. Environmental Science and. Engineering, 12(3), 1-14. https://doi.org/10.1007/s11783-018-1037-8

Kraszkiewicz, A., Kachel-jakubowska, M., \& Niedziolka, I. (2017). The Chemical Composition of Ash From the Plant Biomass in Terms of Indicators To Assess Slagging and Pollution of Surface. Fresenium Environmental Bulletin, 26(11), 6383-6389.

Kumar, P., Sandeep Kumar, K. S., \& Kimble, J. C. (2017). Soil carbon sequestration to mitigate climate change and advance food security. Innovative Farming, 2(1), 90-93. https://doi.org/10.1097/ss.0b013e31815cc498

Li, Y., Duan, X., Liu, S., Li, Y., Zhang, X., \& Ye, C. (2017). Changes in Soluble Sugar Accumulation and Activities of Sucrose-Metabolizing Enzymes during Fruit Ripening of Jackfruit, 9(8), 155-166. https://doi.org/10.5539/jas.v9n8p155

Linville, J. L., Shen, Y., Wu, M. M., \& Urgun-demirtas, M. (2015). Current State of Anaerobic Digestion of Organic Wastes in North America Current State of Anaerobic Digestion of Organic Wastes in North America. Current Sustainable Renewable Report, 2, 136-144. https://doi.org/10.1007/s40518-015-0039-4

Lošák, T., Zatloukalová, A., Szostková, M., Hlušek, J., Fryč, J., \& Vítěz, T. (2011). Comparison of the effectiveness of digestate and mineral fertilisers on yields and quality of kohlrabi (Brassica oleracea, L.). Acta Universitatis Agriculturae et silviculturae mendelianae brunensis, 15(3), 117-122. https://doi.org/10.11118/actaun201159030117

Lumadue, M. R., Cannon, F. S., \& Brown, N. R. (2012). Lignin as both fuel and fusing binder in briquetted anthracite fines for foundry coke substitute. Fuel, 97, 869-875. https://doi.org/10.1016/j.fuel.2012.02.061

Mahanta, C. L., \& Kalita, D. (2015). Processing and Utilization of Jackfruit Seeds. Processing and Impact on Active Components in Food, 395-400. https://doi.org/10.1016/B978-0-12-404699-3.00047-0

Meegoda, J. N., Li, B., Patel, K., \& Wang, L. B. (2018). A Review of the Processes, Parameters , and Optimization of Anaerobic Digestion. International Journal of Environmental Research and Public Health, 15, 2225. https://doi.org/10.3390/ijerph15102224

Menya, E., Alokore, Y., \& Ebangu, B. O. (2013). Biogas as an alternative to fuelwood for a household in Uleppi sub-county in Uganda. Agric. Eng. Int: CIGR Joournal, 15(1), 50-58. 
Mkini, R. I., \& Bakari, Z. (2015). Effect of Moisture Content on Combustion and Friability Characteristics of Biomass Waste Briquettes Made By Small Scale Producers in Tanzania. International Journal of Engineering Research and Reviews, 3(1), 66-72.

Mondal, C., Remme, R. N., Mamun, A. A., Sultana, S., Ali, M. H., \& Mannan, M. A. (2013). Product Development from Jackfruit (Artocarpus heterophyllus) and Analysis of Nutritional Quality of the Processed Products, 4(1), $76-84$.

Montgomery, L., \& Bochmann, G. (2014). Pretreatment of feedstock for enhanced biogas production. Retrieved March 17, 2020, from https://www.nachhaltigwirtschaften.at/resources/iea_pdf/reports/iea_bioenergy_task37_study_pretreatment. pdf

Moomaw, W., Komimoto, M., Urama, K., Brucknew, T., Krey, V., Sterner, M., \& Wiser, R. (2014). Introduction. IPCC special report on renewable energy sources and climate change mitigation, cambridge university press, cambridge, United kingdom and New York, NY, USA. https://doi.org/10.1002/9781119994381

Morales-polo, C., Cledera, M., \& Soria, B. Y. M. (2018). Reviewing the Anaerobic Digestion of Food Waste: From Waste Generation and Anaerobic Process to Its Perspectives. Applied Sciences, 8, 1804. https://doi.org/10.3390/app8101804

Muazu, R. I., \& Stegemann, J. A. (2015). Effects of operating variables on durability of fuel briquettes from rice husks and corn cobs. Fuel Processing Technology, 133, 137-145. https://doi.org/10.1016/j.fuproc.2015.01.022

Musa, N. A. (2012). Determination of Chemical Compositions, Heating Value and Theoretical Parameters of Composite Agricultural Waste Briquettes. International Journal of Sceince and Engineering Research, 3(6), $1-5$.

Nakintu, J. et al. (2019). Ethno-varieties and distribution of jackfruit tree (Artocarpus heterophyllus Lam.) in Uganda : implications for trade, food security and germplasm conservation.

Nansubuga, I., Banadda, N., Babu, M., Devriez, J., Verstraete, W., \& Rabaey, K. (2015). Enhancement of biogas potential of primary sludge by co-digestion with cow manure and brewery sludge. https://doi.org/10.3965/j.jiabe.20150804.1616

Ndhlovu, M., Kiggundu, N., Wanyama, J., \& Banadda, N. (2017). Effects of Incorporating Biochar into the Soil Using Power Tiller and Ox-Plough. Sustainable Agriculture Research, 6(4), 93. https://doi.org/10.5539/sar.v6n4p93

Ndyomugyenyi, E. K., Okot, M. W., \& Mutetikka, D. (2014). Production and availability of Jackfruit ( Artocarpus heterophyllus ) and Java Plum ( Syzygium cumini ) beans for livestock feeding in Eastern and Central Regions of Uganda. Livestock Research for Rural Development, 26(4).

Notaris, C. De, Sørensen, P., Bjarne, H., \& Radziah, M. (2018). Nitrogen fertilizer replacement value of digestates from three green manures. Nutrient Cycling in Agroecosystems, 112(3), 355-368. https://doi.org/10.1007/s10705-018-9951-5

Nsubuga, D., Banadda, N., \& Kiggundu, N. (2019). Innovations in Value-Addition of Agricultural By-Products in Uganda. Journal of Environmental Protection, 10(11), 1493-1506. https://doi.org/10.4236/jep.2019.1011089

Nyamweha, R. B., \& Kebirungi, J. (2018). Jackfruit potential for livestock. Retrieved from https://www.researchgate.net/publication/322909590_Jack_fruit_potential_for_livestock

Obi, O. F., Akabuo, C. O., \& Okonkwo, W. I. (2013). Development of an Appropriate Briquetting Machine for Use in Rural Communities. International Journal of Engineering and Advanced Technology, 2(4), 578-582.

Omulo, G., Willett, S., Seay, J., Banadda, N., Kabenge, I., Kiggundu N., \& Zziwa, A. (2017). Characterization of Slow Pyrolysis Wood Vinegar and Tar from Banana Wastes Biomass as Potential Organic Pesticides. Journal of Sustainable development, 10(3), 81-92. https://doi.org/10.5539/jsd.v10n3p81

Onukak, I. E., Mohammed-dabo, I. A., Ameh, A. O., Okoduwa, I. R. S., \& Fasanya, O. O. (2017). Production and Characterization of Biomass Briquettes from Tannery Solid Waste. Recycling, 2(17). https://doi.org/10.3390/recycling2040017

Owusu, P. A., Banadda, N., Zziwa, A., Seay, J., \& Kiggundu, N. (2017). Reverse engineering of plastic waste into useful fuel products. Journal of Analytical and Applied Pyrolysis, 130, 285-293. https://doi.org/10.1016/j.jaap.2017.12.020 
Pathak, P. D., Mandavgane, S. A., \& Kulkarni, B. D. (2017). Fruit peel waste : characterization and its potential uses. Current Science, 113(3), 1-11.

Pavithran, D. et al. (2015). A Study on the Influencing Parameters on Biogas Production from Jackfruit waste Feedstock. International Journal of Engineering and Management Research, 5(2), 10-13.

Phichai, K., Pragrobpondee, P., Khumpart, T., \& Hirunpraditkoon, S. (2013). Prediction Heating Values of Lignocellulosics from Biomass Characteristics. International Journal of Chemical , Molecular, Nuclear, Materials and Metallurgical Engineering, 7(7), 532-535.

Phung, L. D., \& Dung, D. Van. (2018). Biogas Quality across Small-Scale Biogas Plants: A Case of Central Vietnam. Energies, 11, 1794. https://doi.org/10.3390/en11071794

Pratiwi, Y., Waluyo, J., Widyawidura, W., \& Noviansyah, M. (2019). Development of Jackfruit Peel Waste as Biomass Energy : Case Study for Traditional Food Center in Yogyakarta. International Journal of Renewable Energy Research, 9(4), 2138-2135.

Priya, S. D., Suneta, T., Gupta, M. J., Thangam, M., \& Singh, N. P. (2014). A guide to Jackfruit Cultivation and Value addition. Technical bulletin No.41, ICAR (RC), Goa. Retrieved from https://krishi.icar.gov.in/jspui/bitstream/123456789/2653/1/Technical\%20Bulletin\%20No.\%2041.pdf

Quartey, E. T. (2014). Briquetting agricultural waste as an energy source in Ghana Briquetting agricultural waste as an energy source in Ghana. Recent Researches in Environment, Energy and Pollution, 200-204.

Rabii, A., Aldin, S., Dahman, Y., \& Elbeshbishy, E. (2019). A Review on Anaerobic Co-Digestion with a Focus on the Microbial Populations and the Effect. Energies, 12, 1106. https://doi.org/10.3390/en12061106

Rai, P. J., Tassew, F. A., Parajuli, S., \& Shah, S. (2016). Laboratory-scale Biogas Production from Food Waste in Batch Reactor under Mesophilic Condition. https://doi.org/10.13140/RG.2.1.3780.5680

Raj, S. A. A., \& Ranganathan, V. T. (2018). Characterization of cellulose from jackfruit (Artocarpus integer) peel. Journal of Pharmacy Research, 12(3), 311-315. https://doi.org/10.18006/2018.6(2).414.424

Raju, A. I. Ch., Jyothi, R. K., Satya, M., \& Praveena, U. (2014). Studies on development of fuel briquettes for household and industrial purpose. International Journal of Research in Engineering and Technology, 3(2), $54-63$.

Ranasinghe, R. A. S. N., \& Marapana, R. A. U. J. (2019). Effect of Maturity Stage on Physicochemical Properties of Jackfruit (Artocarpus heterophyllus Lam.) flesh. World Journal of Dairy and Food Science, 14(1), 17-25. https://doi.org/10.5829/idosi.wjdfs.2019.17.25

Ranasinghe, R. A. S. N. Maduwanthi, S. D. T., \& Marapana, R. A. U. J. (2019). Nutritional and Health Benefits of Jackfruit (Artocarpus heterophyllus Lam.): A Review. International Journal of Food Science. https://doi.org/10.1155/2019/4327183

Sebola, R., Tesfagiorgis, H., \& Muzenda, E. (2014). Production of Biogas through Anaerobic Digestion of various Waste : Review. Proceedings of International Conference on chemical, inntergated waste management and envirnomental engineering from 14-16 ${ }^{\text {th }}$, April, 2014 in Johannesburg, South Africa.

Shabih, F., Amir, H., Muhammad, N., Temoor, A., Muhammad, S., Mohsin, T., ... Tabassum, R. (2018). Lignocellulosic Biomass: A Sustainable Bioenergy Source for Future Lignocellulosic Biomass: A Sustainable Bioenergy Source for the Future. Protein and Peptide Letters, 25(2), 1-16.

Shrinath, M., Ramachandrayya, A., Haniadka, R., Dsouza, J., \& Bhat, H. P. (2011). Phytochemistry , nutritional and pharmacological properties of Artocarpus heterophyllus Lam (jackfruit): A review. Food Research International, 44(7), 1800-1811. https://doi.org/10.1016/j.foodres.2011.02.035

Shyamalee, D., Amarasinghe, A. D. U. S., \& Senanayaka, N. S. (2015). Evaluation of different binding materials in forming biomass briquettes with saw dust. International Journal of Scientific and Research Publications, $5(3), 1-8$.

Singh, M., Sarkar, B., Sarkar, S., Churchman, J., Bolan, N., Mandal, S., \& Beerling, D. J. (2018). Stabilization of Soil Organic Carbon as Influenced by Clay Mineralogy. Advances in Agronomy, 148, 33-84. https://doi.org/10.1016/bs.agron.2017.11.001

Smetanová, A., Dotterweich, M., Diehl, D., Ulrich, U., \& Fohrer, N. (2012). Influence of biochar and terra preta substrates on wettability and erodibility of soils. Zeitschrift Fur Geomorphologie, 57(1), 111-134. https://doi.org/10.1127/0372-8854/2012/S-00117 
Sofyan, S., \& Subiyanto, B. (2014). Characterization of Biomass Pellet made from Solid Waste Oil Palm Industry. Proceedings in the 4th International Conference on Sustainable Future Security, SustaiN 2013,20, 336-341. https://doi.org/10.1016/j.proenv.2014.03.042

Sohi, S. P. (2012). Carbon storage with benefits. Science, 338(6110), 1034-1035. https://doi.org/10.1126/science.1225987

Srivastava, N. S. L., Narnaware, S. L., Makwana, J. P., Singh, S. N., \& Vahora, S. (2014). Investigating the energy use of vegetable market waste by briquetting. Renewable Energy, 68, 270-275. https://doi.org/10.1016/j.renene.2014.01.047

Sukarta, I. N., Sastrawidana, I. D. K., Putu, N., \& Ayuni, S. (2018). Proximate Analysis and Calorific Value of Pellets in Biosolid Combined with Wood Waste Biomass. Journal of Ecological Engineering, 19(3), 185190.

Sundarraj, A. A., \& Ranganathan, V. T. (2017). Physicochemical characterization of Jackfruit (Artocarpus integer (Thumb.).). Research Journal of Pharmaceutical, Chemical and Biological Sciences, 8(3), 2285-2295.

Sundarraj, A. A., \& Ranganathan, V. T. (2018). Jackfruit Taxonomy and Waste Utilization Vegetos: An International Journal of Jackfruit Taxonomy and Waste Utilization. International Journal of Plant Research and Biotechnology, 31(1), 67-73. https://doi.org/10.5958/2229

Suryaningsih, S., Nurhilal, O., Yuliah, Y., \& Mulyana, C. (2017). Combustion quality analysis of briquettes from variety of agricultural waste as source of alternative fuels. In International Cobference on Biomass: Technology, Application and Sustainable Development, 65. https://doi.org/doi:10.1088/17551315/65/1/012012 Combustion

Sutrisno, Anggono, W., Suprianto, F. D., Kasrun, A. W., \& Siahaan, I. H. (2017). The effects of particle size and pressureon the combustion characteristics of cerbera manghasleaf briquettes. ARPN Journal of Engineering and Applied Sciences, 12(4), 931-936.

Swami, S. B., \& Kalse, S. B (2018). Jackfruit (Artocarpus heterophyllus): Biodiversity, Nutritional Contents and health. https://doi.org/10.1007/978-3-319-54528-8.

Swami, S. B., Thakor, N. J., Haldankar, P. M., \& Kalse, S. B. (2012). Jackfruit and Its Many Functional Components as Related to Human Health : A Review. Comprehensive reviews in food science and food safety, 11, 565-576. https://doi.org/10.1111/j.1541-4337.2012.00210.x

Tamilvanan, A. (2015). Preparation of Biomass Briquettes using Various Agro- Residues and Waste Papers. Journal of Biofuels, 4(2), 47-55. https://doi.org/10.5958/j.0976-4763.4.2.006

Tayyab, M., Noman, A., Islam, W., Washeed, S., Arafat, Y., Ali, F., ... Lin, W. (2018). Bioethanol production from lignocellulosic biomass by environment-friendly pretreatment methods: a review. Applied Ecology and Environmental Research, 16(1), 225-249.

Teghammar, A. (2013). Biogas Production from Lignocelluloses: Evaluation (Unpublisehed Ph.D thesis). Chalmers University of Technology, Gotenorg, Sweden.

Tembe, E., Azeh, E., \& Ekhuemelo, D. (2017). Effect of Particle Size on Quality of Briquettes Produced from Sawdust of Daniella oliveiri and Gmelina arborea in Makurdi, Benue State, Nigeria. Asian Research Journal of Agriculture, 3(4), 1-7. https://doi.org/10.9734/arja/2017/32079

Tembe, E. T., Otache, P. O., \& Ekhuemelo, D. O. (2014). Density, Shatter index , and Combustion properties of briquettes produced from groundnut shells, rice husks and saw dust of Daniellia oliveri. Journal of Applied Biosciences, 82, 7372-7378. https://doi.org/http://dx.doi.org/10.4314/jab.v82il.7

Teodorita, A. S., Rutz, D., Prassl, H., Kottner, M., Finsterwalder, T., Volk, S., \& Janssen, R. (2013). The biogas handboook. Woodhead Publishing Limited. https://doi.org/10.1533/9780857097415.2.267.

Tiwari, A. K., \& Vidyarthi, A. S. (2015). Nutritional Evaluation of Various Edible Fruit Parts of Jackfruit (artocarpus heterophyllus) at Different Maturity Stages. International Journal of Chemical and Pharmaceutical Review and Research, 1, 21-26.

Tsapekos, P. (2017). Ehancing biogsa production from recalcitrant lignocellulosic residues (Unpublished Ph.D thesis). Technical University of Denmark, Kongens Lyngby, Denmark.

Umeghalu, I., Okwonko, I., Ngini, J., \& Okoye, C. (2015). Performance Evluation of Biogas Yield from Jackfruit waste Co-digestion with Cow Paunch and droppings in Batch Mode. International Journal of Agriculture and 
Biosciences, 4(1), 35-37.

UNDP. (2015). Sustainable Development Goals. Rtrieved March 24, 2020, from https://www.undp.org/content/dam/undp/library/corporate/brochure/SDGs_Booklet_Web_En.pdf

UNFCCC. (2015). The Paris agreement summary. Retrieved March 27, 2020, from https://climatefocus.com/sites/default/files/20151228\%20COP\%2021\%20briefing\%20FIN.pdf

Victor, R., Shajin, S., Roshni, R. M., \& Asha, S. R. (2014). Augmentative Invention of Biogas from the Agronomic Wastes Using Facultative Anaerobic Bacterial strain. International Journal of Current Microbiology and Applied Sciences, 3(4), 556-564.

Vijayaraghavan, K., Ahmad, D., \& Ibrahim, M. K. Bin. (2006). Biohydrogen generation from jackfruit peel using anaerobic contact filter. International Journal of Hydrogen Energy, 31(5), 569-579. https://doi.org/10.1016/j.jhydene.2005.06.006

Vilela, N., Augusta, A., \& Rezende, P. (2016). Evaluation of briquettes made from textile industry solid waste. Energy, 91, 417-424. https://doi.org/10.1016/j.renene.2016.01.075

Waghmare, R., Memon, N., Gat, Y., Gandhi, S., Kumar, V., \& Panghal, A. (2019). Jackfruit seed: an accompaniment to functional foods. Brazilian Journal of Food Technology, 22, 1-9. https://doi.org/https://doi.org/10.1590/1981-6723.20718

Walsh, J., Jiones, D. L., Chadwick, D. R., \& Williams, A. P. (2018). Repeated application of anaerobic digestate, undigested cattle slurry and inorganic fertilizer N : impact on pasture yield and quality. Grass and Forage Science, 73, 758-763. https://doi.org/10.1111/gfs.12354

Waluyo, J., \& Pratiwi, Y. (2018). Analysis Proximate, Ultimate, and Thermal Gravimetric Based on Variations Dimensions of Briquettes from Waste Jackfruit Crust. International Journal of Scientific Engineering and Science, 2(10), 36-39.

Waluyo, J., Pratiwi, Y., \& Sukmawati, P. D. (2017). Biochar Briquette from Jackfruit Crust: Production , Mechanical and Proximate Properties, International Journal of Scientific Engineering and Science, 1(11), $42-44$.

Wang, X., Guo, W., \& Wen, Y. (2019). Effects of temperature on lignocellulosic wastes hydrolysis and volatile fatty acids accumulation under neutral and strongly alkaline conditions. Proceedings of IOP Conference Series: Earth and Environmental Science 358 (2019) 022050. https://doi.org/10.1088/1755$1315 / 358 / 2 / 022050$

Westerholm, M., Castillo, M. D. P., Chan Andersson, A., Jahre Nilsen, P., \& Schnürer, A. (2019). Effects of thermal hydrolytic pre-treatment on biogas process efficiency and microbial community structure in industrial- and laboratory-scale digesters. Waste Management, 95, 150-160. https://doi.org/10.1016/j.wasman.2019.06.004

Winsley, P. (2007). Biochar and bioenergy production for climate change mitigation. Nealand Science Review, 64(1), 5-10.

World Bank. (2016). Estimating international poverty lines from comparable national thresholds. Policy Research Working Paper 7606. https://doi.org/10.1007/s10888-016-9327-5

Xu, S., Liu, J., Huang, X., Du, L., Shi, F., Dong, R., Kaizheng, X., \& Cheong, K. (2018). Ultrasonic-microwave assisted extraction, characterization and biological activity of pectin from jackfruit peel. $L W T, 90,577-582$. https://doi.org/10.1016/j.lwt.2018.01.007

Zhang, He, J., Tian, M., Mao, Z., Tang, L., Zhang, J., \& Zhang, H. (2011). Bioresource Technology Enhancement of methane production from cassava residues by biological pretreatment using a constructed microbial consortium. Bioresource Technology, 102(19), 8899-8906. https://doi.org/10.1016/j.biortech.2011.06.061

Zubairu, A., \& Gana, S. A. (2014). Production and Characterization of Briquette Charcoal by Carbonization of Agro-Waste. Energy and Power, 4(2), 41-47. https://doi.org/10.5923/j.ep.20140402.03

\section{Copyrights}

Copyright for this article is retained by the author(s), with first publication rights granted to the journal.

This is an open-access article distributed under the terms and conditions of the Creative Commons Attribution license (http://creativecommons.org/licenses/by/4.0/). 